九州大学学術情報リポジトリ

Kyushu University Institutional Repository

\title{
CHRYSOMELIDAE OF THE YAEYAMA GROUP (Coleoptera) III
}

Kimoto, Shinsaku

https://doi.org/10.5109/2359

出版情報: ESAKIA. 7, pp.69-70，1969-01-31. Hikosan biological laboratory, Faculty of Agriculture, Kyushu University バージョン :

権利関係 : 


\title{
CHRYSOMELIDAE OF THE YAEYAMA GROUP (Coleoptera) III *†
}

\author{
B Y
}

\section{Shinsaku Кгмото}

This paper deals with the material which was not available when I had completed the previous paper. Some of the specimens taken from Okinawa Is. are also treated.

All the specimens here treated are preserved in the SESKU Collection of Entomological Laboratory, Kyushu University.

\section{Subfamily Galerucinae}

Aulacophora femolaris (Motschulsky, 1857)

Nago, Okinawa Is. (1 ex., 9. ix. 1962, M.-T. Chûjô leg.).

Nagura, Ishigaki Is. (1 ex., 2. ix. 1962, M.-T. Chûjô leg.).

Ishigaki Is. (1 ex., 7. viii. 1962, M.--T. Chûjô leg.).

Aulacophora nigripennis nitidipennis Chû jô, 1935

Nago, Okinawa Is. (1 ex., 9. ix. 1962, M.-T. Chû jô leg.).

\section{Subfamily Alticinae}

Luperomorpha birmanica (Jacoby, 1892)

Komi, Iriomote Is. (1 ex., 18. vii. 1963, Y. Miyatake leg.).

Sphaeroderma quadrimaculata Chû jô, 1935

Nagura, Ishigaki Is. (2 exs., 2. ix. 1962, M.-T. Chû jô leg.).

* Contribution Ser. 2, No. 26. Hikosan Biological Laboratory, Kyushu University, Hikosan.

† The manuscript of this paper was completed in 1965 and sent to the office of the Scientific Expedition Society of Kyushu University. In my several papers, this paper was referred as in press in "Reports of the Committee on Foreign Scientific Research, Kyushu University, no. 3." However, no. 3 of the reports has not been published yet. 
H emipyxis quadrimaculata (Jacoby, 1892)

Kawahara and Ohama, Ishigaki Is. (1 ex., 2. viii. 1963, Y. Miyatake leg.).

M anobia gressitti Nakane \& Kimoto, 1961

Komi, Iriomote Is. (7 exs., viii. 1962, M.-T. Chûjô leg.).

Aphthona formosana Chen, 1934

Nagura, Ishigaki Is. (1 ex., 2. ix. 1962, M.-T. Chûjô leg.).

Altica cyanea (Weber, 1801)

Ohara, Iriomote Is. (1 ex., 8-18. viii. 1962, M.-T. Chûjô leg.).

\section{Subfamily Cassidinae}

Laccoptera quadrimaculata (Thunberg, 1798)

Ohtomi, Iriomote Is. (2 exs., 10. viii. 1962, M.-T. Chû jô leg.).

\section{Literature}

Kimoto, S. 1963. Chrysomelidae of the Yaeyama Group (Coleoptera) I. Reports of the Committee on Foreign Scientific Research, Kyushu Univ. 1: 103-105. (in Japanese with English summary).

Kimoto, S. 1964. Chrysomelidae of the Yaeyama Group (Coleoptera) II. Ibid, 2: 149-156. 